\title{
Wychowanie a polityka. Toruńskie konferencje naukowe
}

Wychowanie a polityka to obszar zainteresowań naukowych pracowników Zakładu Historii Wychowania i Myśli Społecznej Instytutu Pedagogiki UMK. Problematyka ta znalazła wyraz w organizowanych przez ten zakład konferencjach naukowych. Pierwsza $z$ nich, mająca miejsce w 1996 roku, poświęcona była rozważaniom ogólnym w obrębie tej problematyki i nosiła tytuł Wychowanie a polityka. Tradycje i wspólczesność (sprawozdanie „Biuletyn Historii Wychowania” 1997). Jej owocem jest obszerna publikacja o tym samym tytule, zawierająca materiały pokonferencyjne.

W 1997 roku zorganizowano kolejne spotkanie naukowe, którego temat brzmiał. Wychowanie a polityka. Między wychowaniem narodowym a państwowym.

Wzięli w niej udział przedstawiciele kilku ośrodków naukowych, którzy w oparciu o różnorodne źródła ukazali złożony obraz formowania się koncepcji wychowania narodowego i państwowego na tle przemian politycznych i społecznych. Tak sformułowany temat dal możliwość wielostronnych analiz, a także zaprezentowania różnorodnych aspektów glównego zagadnienia, a mianowicie:

- relacji polityka a wychowanie w okresie rozkwitu Cesarstwa Rzymskiego,

- koncepcji wychowania w okresie staropolskim,

- postaw narodu litewskiego wobec Polaków na przełomie XIX i XX w.,

- koncepcji jednostki w doktrynie euroazjatyzmu,

- wychowawczych propozycji obozu narodowego,

- znaczenia Polskiej Macierzy Szkolnej w wychowaniu obywatelskim,

- ewolucji idei wychowania obywatelskiego w polskiej myśli pedagogicznej,

- problemu syntezy wychowania narodowego i państwowego,

- kwestii edukacji obywatelskiej w poglądach wychowawczych i działalności ludowców,

- elementów narodowych i państwowych w katolickiej koncepcji wychowania społecznego,

- idei państwa w poglądach F. Konecznego i J. Woronieckiego oraz

- roli wychowania dla społeczeństwa w świetle publicystyki „Tygodnika Powszechnego”.

Referaty na ten temat zaprezentowali: J. Jundziłł, D. Żołądź-Strzelczyk, J. Waskan, R. Bācker, W. Wojdyło, J. Góralski, R. Jadczak, K. Jakubiak, A. Wojtas, W. Jamrożek, M. Strzelecki, K. Kalinowska i M. Strzelecka.

Materiały z niniejszej konferencji zostały już opublikowane, dzięki czemu zainteresowani czytelnicy mają możliwość zapoznania się z ujęciem i interpretacją wymienionych wyżej zagadnień.

11 grudnia 1998 roku odbyła się trzecia konferencja z cyklu: Wychowanie a polityka. Tym razem tematem obrad były: Mity $i$ stereotypy w polskiej myśli spolecznej $X X$ wieku. Konferencja zgromadziła po raz kolejny przedstawicieli różnych specjalności polskich uczelni. Program jej został wypełniony wystąpieniami badaczy, którzy zaprezentowali wyniki swoich badań pozostające w kręgu problematyki zakreślonej głównym tematem.

Cechą charakterystyczną tej konferencji było przekrojowe, syntetyczne ujmowanie prezentowanych zagadnień. Ponadto $w$ wystąpieniach podniesione zostały najważniejsze a czasem najbardziej „drażliwe” sfery życia społecznego, takie jak: edukacja, polityka, nauka i religia.

Podczas obrad zostały przedstawione problemy szczegółowe, uwzględniające różnorodne aspekty i fenomen mitu i stereotypu w polskiej myśli społecznej. Kolejni referenci w osobach A. Wojtas, J. Waskan, K. Jakubiak, W. Jamrożek, W. Wojdyło, W. Tyburski, M. Strzelecki, G. Radomski, J. Góralski, K. Kalinowska, M. Strzelecka, R. Băcker i W. Szulakiewicz w swoich wystąpieniach zajmowali się następującymi zagadnieniami:

- mit demokracji politycznej a demokracja,

- stereotyp granic Rzeczypospolitej w myśli politycznej obozu narodowego, 
- kategoria państwa w kształtowaniu koncepcji wychowania państwowego,

- edukacja w procesie przeobrażeń społeczno-kulturalnych wsi i kraju,

- stereotyp Żyda w publicystyce obozu narodowego,

- wolność nauki w Szkole Lwowsko-Warszawskiej a współczesność,

- stereotyp społeczeństwa polskiego w myśli politycznej obozu piłsudczykowskiego,

- asymilacja przez wychowanie w koncepcjach Narodowej Demokracji,

- wizerunek działacza kulturalno-oświatowego w poglądach reprezentantów Polskiej Macierzy Szkolnej,

- społeczeństwo, a stereotypy w obliczu nauki Kościoła Katolickiego,

- obraz katolika na lamach "Tygodnika Powszechnego"

- wychowanie po polsku. Stereotypy polskości i patriotyzmu i próby ich przezwyciężania.

Ogólnie można powiedzieć, iż autorzy objęli w swoich referatach czasy I połowy XX wieku, z dominacją okresu II Rzeczypospolitej.

Analizując programy toruńskich konferencji i publikacje materiałów pokonferencyjnych można wyłonić kilka płaszczyzn, w obrębie których toczyły się rozważania uczestników tychże spotkań. Z wielostronnych ujęć w przedstawionych wypowiedziach wynika, iż wychowanie i polityka funkcjonowały na przestrzeni dziejów jako:

- podstawowa relacja w koncepcjach wychowawczych przedstawicieli poszczególnych epok,

- narzędzie realizacji programów politycznych: ugrupowań, obozów politycznych i organizacji,

- płaszczyzna realizacji dążeń budowy struktur spolecznych narodu i państwa,

- element koncepcji edukacyjnych, wyrażających się $w$ ideałach wychowawczych $\mathrm{i}$ modelach kształcenia jednostki.

W świetle tych wielostronnych analiz rodzi się jednoznaczne przeświadczenie, iż polityce potrzebna jest pomoc pedagogii i odwrotnie, wychowaniu niezbędne jest wsparcie polityki. Ta pierwsza tym jest „rozumniejsza” im bardziej sq oświeceni jej przedstawiciele. Druga zaś (pedagogika) może się rozwijać, gdy jest ochraniana (a nie ograniczana) przez polityków i ich działania.

Głosy pedagogów, historyków wychowania, historyków, socjologów, politologów i filozofów sprawiają iż mamy do czynienia z różnym spojrzeniem na te same zagadnienia o charakterze: ogólnospołecznym, ogólnoludzkim, ogólnooświatowym. To sprawia, że powstaje często całościowy obraz uwarunkowań procesów edukacyjnych i czynników ich rozwoju.

W kolejnych toruńskich spotkaniach naukowych wyłaniają się inne przejawy „logiki” stosunków miedzy wychowaniem a polityką. Bowiem polityka jest sztuką bycia, sztuką zwycięstwa, bardzo często za wszelką cenę. Ponadto ma potężniejsze środki oddziaływania na spoleczeństwo. A wychowanie (ze swego założenia) jest sztuką ludzkiego trwania i przygotowania młodych pokoleń do takiego humanistycznego trwania. Głosowi polityków domagających się władzy towarzyszy przestroga ze strony środowiska pedagogicznego: władza nie nad wszystkimi i nie nad wszystkim! W tekstach będących owocem spotkań, tworzy się przekonanie, iż polityka nie utraciła i nie chce utracić mocy panowania nad życiem społecznym, ubierając się czasem w „pedagogiczną szatę" działania A pedagogika? Ta, próbuje „wciskaćn się do polityki, ale ma łagodniejszą postać, subtelniejsze metody, a nade wszystko nie może posługiwać się siłą. I w tym momencie pojawia się pytanie: czy aby te same prawa rządzą logiką porządku pedagogicznego i politycznego?, czy wola polityczna ma wspólny obszar z wolą pedagogiczną?. Miejmy nadzieję, iż odpowiedzi na te pytania udzielą, być może, następne konferencje w Toruniu. Nie wdając się w tej kwestii w rozważania merytoryczne, lecz sugerując się jedynie doświadczeniami przeszłości i życia codziennego można stwierdzić, iż zarówno polityka, jak i pedagogika mają wspólny podmiot i obszar oddziaływania, ludzką psychikę, ludzkie postawy i moralność. 